\title{
Islam, indigeneity, and religious difference in a secular context: Canadian case studies
}

Fachrizal Halim ${ }^{1^{*}}$

${ }^{1}$ Department of Religion and Culture, St. Thomas More College, University of Saskatchewan, Canada

*Corresponding author

E-mail address: fhalim@stmcollege.ca

DOI: https://doi.org/10.21107/sml.v4i2.11538

\begin{tabular}{|c|c|}
\hline Article Info & A BStRACT \\
\hline Keywords: & This paper analyzes the hardening religious difference in contemporary \\
\hline Indigenous-Muslim & Canadian society and explains why the presence of Muslims, including \\
\hline $\begin{array}{l}\text { Religious } \\
\text { difference }\end{array}$ & $\begin{array}{l}\text { new converts, constantly incites in the public imagination the primordial } \\
\text { threat of Islam to the secular accomplishments of Canadian society. Relying }\end{array}$ \\
\hline Secularism & $\begin{array}{l}\text { on the available data and previous research on the historical formation of } \\
\text { the secular in Canada, the author attempts to detect a paradox within the }\end{array}$ \\
\hline $\begin{array}{l}\text { Politics of } \\
\text { recognition }\end{array}$ & $\begin{array}{l}\text { state-lead politics of recognition that unintentionally creates the conditions } \\
\text { for new communal conflicts. By using an inductive generalization, the }\end{array}$ \\
\hline Cree & $\begin{array}{l}\text { values is derived not so much from cultural and theological differences or } \\
\text { actual political threats posed by Muslims or Indigenous converts. It instead } \\
\text { emanates from the self-understanding of the majority of Canadians that } \\
\text { defined the nation as essentially Christians and simultaneously secular. }\end{array}$ \\
\hline
\end{tabular}

\section{Citation suggestion:}

Halim, F. (2021). Islam, indigeneity, and religious difference in a secular context: Canadian case studies. Simulacra, 4(2), 185-200. https://doi.org/10.21107/sml.v4i2.11538

Received 21 August 2021; Received in revised form 2 October 2021; Accepted 3 October 2021; Published online 25 November 2021. 


\section{Introduction}

Major world events in recent years, such as violent extremism, global migration, and the refugee crisis, have sustained the focus on Islam and the Muslim community in the West. To mainstream media's audiences and the general public, the presence of Muslims in secular Western countries poses an existential threat as they are perceived to have maintained values and practices contradictory to secular society's achievements. Recent cases showing how some individual Muslims had engaged violent extremism against the West reinforce the familiar narrative that their 'religiosity' threatens secular society's existence and accomplishments, such as freedom, democracy, and a tolerant way of life. The repercussions of such a perceived threat can instigate further discrimination, hate speech, or even actual assault against Muslims, as recently happened in London, Ontario (2021), and Québec City (2017).

For many years now, scholars in the interdisciplinary study of religion have addressed the perceived conflict between Islam and the secular West as constructed, situational, and deliberately reductive. Common among scholars in the field is to treat Islam and Muslim minority as 'foreign' to the majority of Christians and the secular Canadianstate.Some of the current debates on Islam and the Muslim community in Canada addressed the early Muslim community (Marhall \& Mayes, 2016) and how Muslim immigrants in Canada could fully integrate into secular Western democracy (Kazemipur, 2014). Others argued for a pluralizing conceptualization of the secular that captures day to day interactions between Muslims and Canadian society that reflects a deep commitment to equality (Beaman, 2017) and the importance of analyzing how individual Muslims, including their second generations, negotiate their identity and belonging to the faith in secular society (Ramji, 2014). Equally important is the security issues surrounding individuals engaged in extremism and participated in foreign countries' conflicts as a lens for studying Islam and Muslims in Canada (Flower \& Birkett, July 2014). As the public and policymakers have become aware, the phenomenon has gained a new level of incommensurability with the rise of Indigenous individuals who became Muslims, creating new hybrid forms of faith and cultural boundaries in contemporary Canada.

In Indigenous Studies, many scholars have equally addressed similar inequitable encounters between Indigenous groups in Canada and the secular settler society. However, one must note that, unlike many immigrant communities who wish to integrate into mainstream Canadian society, the Indigenous community aspires for a different priority, that is, to end the perpetual cycle of oppression through selfdetermination and restore the indigeneity's collective existence resembling a parallel society (Alfred, 2011; Anderson et al., 2000). Hence, scholars in the field focus more on decolonizing hegemonic discourse on Indigenous community, arguing the creation of the 'condition of mutuality' in forms of the collective right of self-recognition (Coulthard, 2014).

Despite the various attempts to discuss the ways to end the marginalization and improve socio-economic conditions of Indigenous community in contemporary Canadian society, the field has yet to accommodate debates on the lived realities of Indigenous individuals who opted an attachment to Islam in their struggle for justice and equality. The encounters between Islamic religiosity and activism and Indigenous heritage in the context of a liberal state have created new hybrid forms of identity, recalibrating collective Indigenous 
cultural autonomy and authenticity and cultural boundaries that remain fluid in the Canadian social fabric. However, scholars in the field are yet to analyze the rich personal experiences that indigenous individuals gained upon conversion and socioreligious differences the converts expressed in the public sphere.

In this study, the author intends to bridge the interdisciplinary study of Islam and Muslim societies and Indigenous Studies that rarely interacted to shed light on the realities of Muslims and their religiosity in the contemporary Canadian context and the encounters between Islam and indigeneity. The author will analyze available data from previous research and media reports surrounding the debates on the reasonable accommodation of Muslims in Québec and the documented conversion of an Indigenous individual to Islam, which was seen as an impending threat to secularism. Borrowing Saba Mahmood's theoretical framework as laid out in her Religious Difference in a Secular Age (2016), the author will revisit the current debates on political secularism, especially on the state-lead politics of recognizing minority Muslims and the Indigenous community in Canada. Following this framework, the author argues that the prerogative role of the secular liberal state to define the nation's norms and identity and its claim to be a neutral solution to manage diversity, distributive justice, and equality to all citizens have exacerbated religious differences and potential communal conflicts. The perceived incompatibility between Islam and indigeneity on the one hand, and Western values on the other, including prejudices against the former groups, are therefore derived not so much from cultural and theological differences or actual political threats posed by the Muslims or indigenous individuals. They instead emanate from, or constitutive of, the inherent understanding of Canada as essentially Christians and simultaneously secular in its political practices and cultural values.

\section{Method}

To elucidate the hardening religious difference in contemporary Canada, the author relies on the available data on the historical formation of the secular in Canada from previous research. These data are documented in cited monographs, book chapters, and statistics. Combined, they provide a glance of how the assembling majority of Anglo-Protestant and French Roman Catholic conceptualized their subjectivities, shared ideals, as well as cultural and political ethos, all of which helped to define collective imaginaries of being Canadians. The same data also provide circumstantial cases and public debates that led to the transformation of Canada as a "Christian" state to a liberal multicultural state that promises to demolish the old forms of hierarchy and creates the condition of civil and political equality for all citizens. Be that as it may, the available data and previous research on political secularism in Canada do not fully explain the problems of contemporary communal religious differences that increasingly intensified. Existing studies on the state-lead politics of recognition and media reports surrounding the reasonable accommodation of Muslims in Québec, the promulgation of secularism law, and the documented conversion of an Indigenous individual to Islam tend to reinforce the narratives that saw religious difference as a primordial conflict between Islamic and the Judeo-Christian civilizations or a product of global jihadism waged against the secular West.

The author will re-examine these available data, integrating Saba Mahmood's theoretical reflection as laid out in her 
Religious Difference in a Secular Age. Applying an inductive generalization, the author will re-read the formation of the secular in Canada and trace the creation of the discursive operation of power that defines social categories (majority, minority, immigrant, indigenous) and common conceptions of ideals (secular, freedom, human rights). Analyzing the formation of the secular and its discursive operation of power can help us detect a generative contradiction within the state-lead politics of recognition. This generative contradiction, in turn, enables us to unravel why Muslims in Western countries are continuously seen as posing an existential threat to the mainstream secular society and why Indigenous converts to Islam are seen as disturbed individuals who reject fundamental Canadian values.

\section{Results and Discussion}

In the last decade, several scholars have examined the various ways in which to reconsider the classical secularization theory by elaborating its basic premises while at the same time showing empirical features or actual practices that confirm or contradict those assumptions. The former reminds us of the popular theory introduced by J. Casanova (2006). It detailed the tripartite conditions of secularity: a decline of religious beliefs and practices, the privatization of religion, and the differentiation of the secular spheres from religious institutions and norms. Following this model, scholars who worked on the secularization process in contemporary Canada have confirmed that the country experienced all the above phenomena, showing the evidence of privatization of religion (Beyer, 2000, pp. 189-210) and differentiation of religious institutions in the areas of social services, public health, and education ( $\mathrm{O}^{\prime}$ Toole, 2006). Added to this arguments is the data from Statistics Canada collected between 1985-2004 that showed a decline in participation of religious worship and membership in church organizations (Clark \& Schellenberg, Summer 2006). The data tells us that while there is evidence of secularization, there is also evidence that contradicts its premise, paving the way for others to argue that the formation of the secular in Canada is an unfinished story. With the increase of evidence that shows the intensification of certain aspects of religiosity and the valuation of identity based on loyalty to a religious tradition, it is therefore critical to revisit how the formations of the secular in Canada were unfolded and then define what it means to be secular in the contemporary Canadian society.

In this context, we can use Saba Mahmood's theoretical reflection in her Religious Difference in a Secular Age to reexamine the formations of the secular in Canada. Central to Mahmood's arguments are the essential features of secularization shared across the Euro-Atlantic states and non-Western world while refraining from creating a homogenous or monolithic genealogy of secularism for all modern states. One of these features is the institutionalization of the modern state, whose central premise centers around private-public distinction and the politics of equal recognition (Mahmood, 2016, p. 9). After establishing the modern secular state, the different assembling of actors began to use their power to achieve and regulate their common goals and determine what is properly religious and what is not, all of which were institutionalized within the state's sovereign authority and its secular apparatus. This practice prompts us to Nikolas Rose (Rose, 1996, p. 43), who suggested that the 'power of the state' is not a cause, but a result of the compositions of various actors and relations of authority that determined norms and practices within that particular state. The state's sovereign power to identify, regulate, and demarcate what we 
called the secular or religious is, therefore, an outcome of the long-term, constant, but incomplete and unstable engagements between various conceptions of ideas and different assembling of actors who tried to achieve their ideals and simultaneously set normative practices to regulate the subjects of the state.

Another aspect that Mahmood highlighted is the centrality of Christianity within the Euro-Atlantic societies. In earlier writing, Mahmood indicated that the "secular and the religious are not opposed to one another but intertwined, both historically and conceptually such that it is impossible to inquire into one without engaging the other" (Mahmood, 2013, p. 140). This observation leads us to reconsider the tripartite descriptions suggested by Casanova above, not by showing evidence that contradicts the standard theory of secularization but by tracing the evolution of the modern secular state and its role in organizing religious life and modern subjectivities. In what follows, I will briefly chronicle the evolution of secularism in Canada, from the Anglo-Protestant and French Roman Catholic collective imaginaries to a liberal multicultural state that promised to demolish the old forms of hierarchy and create the condition of civil and political equality for all citizens.

\section{What it means to be secular in Canada}

Long before the institutionalization of Canada as a liberal secular state, the nation was imagined as a Christian nation by its early settlers or citizens. As it was common among other Euro-Atlantic states, early European settlers used biblical references to describe lands they appropriated as their state and give them a sense of unity as a sovereign community. In his recent study on re-examining religion and secularization in Canada, Paul Bowlby (2014) recalled that when the early Anglo-Protestants supporters of Confederation began to define Canada as a sovereign nation, they used the term "Dominion." Sir Samuel Leonard Tilley (d. 1896), an early supporter of Confederation and the former premier of New Brunswick, proposed the term at the London Conference in 1866, inspired by the Bible (Psalm 72:8, King James Version), "May He have dominion from sea to sea, and from the river to the ends of the earth" (Waite \& Harris, 2008; last modified January 15, 2016). Early European settlers read the Christian scriptures in the King James Version in the churches they built across the new state during the nation-building process. This reading gave the assembling Anglo-Protestant citizens the meanings of their existence, norms, and values that they practiced, and their roles and collective goals as a nation, a sense that perhaps similar to what Benedict Anderson described as "a deep horizontal comradeship" (Anderson, 1983, p. 7). The phrase "Dominion Day" was used to mark the national holiday commemorating Confederation on July 1, until the term "Canada Day" replaced it in 1982.

Responding to the collective imaginary of Canada as a Christian nation as conceived by the majority of Anglo-Protestants, the French Roman Catholics in the country contested it with their vision and distinct identity in Confederation. The old colonial heritage of Roman Catholic tradition in every village of Québec, the Catholic communities and their liturgies therein, and the hierarchy within the Catholic church and its role in the assembling of Québec institutions provided them a different construction of social imaginary of what it meant to be an individual Christian and citizen of Canada (Bowlby, 2014, p. 32). Unlike the AngloProtestants who defined the nation in the biblical term "dominion," the French Roman Catholics used the Christian edifice 
"cathedral" to characterize their vision of Canada. For them, the word "cathedral" contained an aspiration for cultural diversity as an element of being Canadian.

While the two collective imaginaries of a Christian nation proved to be instrumental for creating the bonds of nationhood among fellow European-Canadian citizens, the same imaginaries had detrimental consequences on Indigenous communities in the Dominion. The Canadian Historical Association Booklet published in 1997 summarized various policies of the federal government from 1867 to 1927 that epitomizes how Ottawa controlled the Aboriginal people politically with the creation of Treaties; molded them economically by assigning lands reserved for the 'Indians;' and reshaped them culturally and spiritually through missionary activities and the creation of centralized schooling systems. John A. Macdonald (d. 1891), the first Prime Minister whom contemporary historians see as among those who laid the foundations of modern Canada and put all the most damaging policies toward the Indigenous community, made the coercive assimilation a nationwide program. In an attempt to achieve this goal, Macdonald told the House of Commons in 1882 that he had reason to believe that the agents as a whole were doing all they can, by refusing food until the Indians were on the verge of starvation (Hopper, 2018). Later in 1887, Macdonald restated his policy more openly: "The great aim of our legislation has been to do away with the tribal system and assimilate the Indian people in all respects with the inhabitants of the Dominion." Macdonald understood the vitality of this assimilative policy to the Canadian and Christian social imaginaries; in collaboration with various Christian denominations, the schooling system that began in 1870 continued its operation across Canada (except New Brunswick, Prince Edward Island, and Newfoundland) with more than 150,000 indigenous children were taken from their families and placed in these schools until the government abolished it in 1996. The recent discoveries of 751 unmarked graves at a former residential school in Saskatchewan and 215 remains of children at a similar residential school in British Columbia testify to the schooling system's abuse of the Indigenous community (BBC, 2021).

It became apparent that the Indigenous people were not the only group that went through coercive assimilation into the Victorian Christian imagination of Canada. The majority of Protestants and Roman Catholics extended the policy to newcomers whom they constructed as 'foreigners' or 'immigrants.' As such, the presence of Sikhs, Hindus, and the East Asians individuals on the west coast in the early decades of the twentieth century was seen challenging the Christian bonds of nationhood. With the use of deportation power, among other policies instituted by the majority, these 'immigrants' became the subject of policy that limited their capacity to be engaged citizens. Hence, the Canadian social imaginaries as a Christian nation had a double political function: the politicians used it to mobilize progressive political projects, but they also used it regressively to exclude aboriginal communities and foreigners or recent immigrants.

After the Second World War and following the wave of immigration and civil right struggles in the 1960s, the exclusive Christian definition of nationhood could no longer accommodate the progressive political projects for the modern nation. This realization gave way to the secular imaginary, where multiculturalism emerged as necessary for a democratic society. Among the academics, Charles Taylor is perhaps the most intense scholar who responded to the citizens' demand for equality and elaborated the concept systematically. In one of his writings, Taylor addressed inequality and 
the old pattern of social hierarchy based on honor as the legacies of the ancient régime that were untenable in a democratic society. In place of the old concept of honor, following Taylor, a healthy democratic society requires equal recognition based on a universal concept of dignity of human beings or citizens' dignity. With regards to the collective social imaginary of Canada as a Christian nation, Taylor proposed: "A liberal society must remain neutral on the good life, and restrict itself to ensuring that however they see things, citizens deal fairly with each other and the state deals equally with all" (Taylor, 1994, p. 57). Following this concept, Canada's failure to recognize the dignity of fellow human beings and their identity can cause them to suffer real damage, which contradicts its democratic project and fundamental human values.

Based on the principle of equal recognition, Canada recalibrated its common ideals by enacting the Charter of Rights and Freedom, which is part of the 1982 Constitution Act signed into law on April 17 of the same year. The Charter is a compromise between the dominant Anglo-Protestant and French Roman Catholic traditions and a means to protect minorities against parliamentary majorities. The enactment of the Charter guaranteed that all Canadians, regardless of their culture and religious backgrounds, are equal. In effect, religion was confined to the private sphere, and that the collective imaginary as a Christian nation could no longer command policy and social relationships in the public sphere.

Despite the Christian imaginary could no longer command social relationships and policies, the same imaginary still played a vital role in defining the dominant culture and identity of the majority population in Canada. Since the founding fathers of Canada and its 1982's institutionalization as a liberal multicultural secular state were Christians, what most Canadians think of secularism and the conditions of secularity are the fruit of the ingenious works of prominent Christian figures in the country. It is not by coincident that when Charles Taylor elaborated the concept of multiculturalism in a liberal and secular Canada, he added thoughtfully that liberalism is basically "a fighting creed" and that "the supposedly neutral set of difference-blind principles of the politics of equal dignity is, in fact, $a$ reflection of one hegemonic culture" (emphasis is added) (Taylor, 1994, pp. 43, 62). In the same book, Taylor also discussed that what he meant by 'hegemonic culture' is none but Western Christianity. Using Islam and Muslims as an opposite reference, Taylor wrote:

For mainstream Islam, there is no question of separating politics and religion the way we have come to expect in a Western liberal society...Moreover, as many Muslims are well aware, Western liberalism is not so much an expression of the secular, postreligious outlook that happens to be popular among liberal intellectuals as a more organic outgrowth of Christianity - at least as seen from the alternative vantage point of Islam (Taylor, 1994, p. 62).

Therefore, secularism is not simply the condition of the state's neutrality concerning religion in public. Instead, it was a reflection of the culture of the Christian majority in Canada. What it means to be secular in contemporary Canada is precisely to have the self-realization that the majority's identity as Christians has progressively evolved from transcendental and otherworldly orientations to autonomous individuals who are receptive to democracy, egalitarianism, and social solidarity.

It would be utterly wrong to argue that being secular means relegating religion to be of no importance. On the contrary, being secular does not imply rejecting 
or invalidating Christian ethical values. Christianity remains central to the majority of Canadians such it could claim an ample space in public conversations in the name of culture or heritage. Hence, a common expression such as "your religion is polluted, but our religion is heritage" rides on the logic that, unlike your religion (Islam), our religion (Christianity) and secular culture are inseparable. This dominant culture in the Canadian context often re-manifests as proudly secular while remains essentially Christian when it encounters its binary opposite in the forms of Islamic practices, values, and political ethos. As should be apparent, it is precisely in this context that the presence of Muslims in Canada and recent indigenous converts to Islam are seen as incompatible with the mainstream Canadian society. Not only did Muslims find it difficult to adjust their life to the demands of the secular majority, but their presence in Western society is also constantly seen as a threat to its civilizational identity.

\section{The intensification of Muslim difference}

The contour of the Canadian political history above indicates that secularism, including the values and practices, such as multiculturalism and the policy of equal recognition, are an outcome of the long-term negotiation between various conceptions of ideals from the different assembling of actors that constitute the fabric of the Canadian society. The aggregate of the conceptions of secular ideals above was later compiled in the Charter of Rights and Freedom (1982), which provides a constitutional basis for civil and political equality, irrespective of one's ethnic or religious background. With the establishment of the Charter, which was followed by the Canadian Multiculturalism Act adopted in 1988, existing policy centered on assimilation to the culture of the majority ethnic-European populations no longer adequately met the requirement of Canadian society. Any barriers that prevent full participation in society were expected to be removed and replaced with one that promotes neutrality, inclusivity, and greater recognition of Canada's cultural diversity.

In this case, religion was effectively depoliticized and could no longer command policy and social relationships in the public sphere. But to say that religion was confined to the private sphere and that the Christian imaginary could no longer control social relationships and public policies is not the same as saying that religious power has been tamed and of no importance to many individuals. The Charter promised to dismantle premodern forms of hierarchy and erase the inequality that religion promotes. However, as I shall explain below, the same Charter also enabled religions to flourish in the private sphere, empowering individuals and minority groups to use it to sustain their collective identity.

In the context of a secular and multicultural Canada, Muslims - most of them arrived in the last three decades and emigrated from non-European countries - were no longer under any pressure to assimilate to the host population. Unlike in the earlier period, during which recent immigrants were expected to adopt the majority's language, culture, and lifestyle, the state's recognition policy provides ample room for non-ethnic European, nonChristian, and non-Indigenous to integrate as parts of the Canadian heritage. In one of his writings, Charles Taylor anticipated this condition; "due recognition is not just a courtesy we owe people. It is a vital human need" (1994, p. 26). Recognition, in short, has become a keyword of our time.

The secular constitution was initially the expression of the majority. However, during the course of rehabilitating Canada's past burden committed against the Indigenous community and early immigrant 
communities, the secular constitution opened up ways for minority Muslims to retain their culture and identities while actively participating in the mainstream social, economic force, political life. The drawback is that the same politics of rights and recognition inevitably exposed Muslims' culture, values, practices, making them more visible to the majority population. This visibility, in turn, provided many native-born Canadians with an awareness of Muslims' cultures and the opportunity to interact with them. As should be apparent, the same visibility also created a fear of extinction, anxieties about their economic success or socio-political influence, and eventually tensions in the public sphere.

The liberal policy to accommodate and integrate into Canadian society did not always bring about a positive experience for Muslims. Canadian Muslims did not have the minimal modality to develop a normal social relationship with their surrounding community. Their migration to Canada, or expulsion from their land, as in refugees' cases, abruptly placed them in an environment where they experience a loss of social comfort. In the new world, they immediately face the language barrier needed for communication. Without the physical and emotional support of the community with whom they shared history and background, they lose the common cultural codes necessary for maintaining the identity and social relationship. As Kazemipur (Kazemipur, 2014, p. 145) has elaborated, no matter what social or economic status Muslim immigrants might have in the old country, they always begin a new life in Canada as a newcomer. As such, the social capital necessary for developing long-term social relationships is not there for them upon arrival. The absence of such social capital contributes to Muslims' psychological being, which eventually affects how they live in the new environment.
A common practice among immigrants who experience the loss of a sense of belonging and social network is to return to religion and religious community for fulfilling any sort of comfort needed to live everyday life. Muslim newcomers are no exception. Attending mosques and other religious activities in the new environment enables them to regain some connections with the origins that they left behind due to their migration. Therefore, immigration policy and the freedom to practice religion as promised by the secular state contribute to the proliferation of religion among immigrants who lose their connection with their homeland. Religion, in this case, Islam, plays a significant role in sustaining the collective identity of minority Muslims in the new world. The cumulative effects of the proliferation of religion in the private sphere are what Mahmood called "intensification of religious inequality and conflict" and "the valuation of a certain aspect of religious life over others" (Mahmood, 2016, p. 15). The drawback is that while attending religious activities or maintaining and extending connections with fellow believers in the new country granted Muslims collective material and immaterial supports, such actions may be seen as counterproductive by the mainstream secular society, strengthening the media perception that Muslims are a communal group that prefers to live in and act for its own religious community.

What is also important to consider is how much the mainstream society is willing to interact with minority Muslims. The state's policy of neutrality and recognition will have no impact on the actual communal life of the nation if the majority of the population is unwilling to engage with them. Unlike the newcomers to the country who are perhaps eager to extend connections with the host society, the latter has no need to engage with them, which may take away their resources and become competitors for 
their jobs. Furthermore, given the amount of bias and prejudices accumulated on Islam and the Muslim community as a direct opposite of the Western civilizational identity, the secular society may even feel threatened with the Muslims' presence in their neighborhood and the social and political life. Numerous incidents of hate crimes and actual assault against Muslims precisely corresponded to such perceived threat, which posed a serious question to the promise of equality that the liberal state promoted. Muslims are burdened with a tremendous challenge to adjust to the new environment and overcome negative images of their religiosity and stereotypes against their culture that are already embedded in mainstream secular society. Similar to what the political philosopher Wendy Brown (1995) had detected, the "well-intentioned liberal policy to accommodate and integrate Muslims into the mainstream secular society added the level of incommensurability that Muslims have to deal with, putting them in an increasingly precarious position in the Canadian polity. The policy reproduced the same asymmetrical relations that it initially sought to solve: inequality.

Several cases that appeared in the last few years exemplify how the state's neutrality and equal recognition policy, manifested in the public debates surrounding the controversy of reasonable accommodation, has exacerbated anxiety about others and tension in the public sphere. Consider, for example, the proposed Bill 94 that obliged Québec women to show "un visage décovert" or "naked face" while receiving or giving public services (Fournier \& See, 2014). The case is a good example of how the secular premise to promote neutrality and equality has created anxiety about Muslims' cultural practices. Similarly, the recently passed Bill 62 that reinforced women to uncover their faces while receiving or giving state services demonstrates how the exposition of secular norms about women in a liberal society is pitched against the perceived opposite in the life of traditional Muslim women. Referring to Bill 62, former Québec's Premier Phillippe Couillard made a public statement arguing that all Canadians, not just in Québec, would agree upon the simple norm that public services should be received and given without face covered as some Muslim women did. "I speak to you. You speak to me. I see your face. You see mine. As simple as that," said Phillippe Couillard (Toronto Sun, 2017). This statement captures the tension between the secular political elites and Muslims' moral and ethical claims presented by a small number of Muslim women.

That anxiety and tension in public did not wind down, regardless of who was in charge of the parliament or legislative assembly. After the latest provincial election that put the Coalition Avenir Québec (CAQ) into power, Canadians witnessed more vigorous public and political concerns about Muslims' 'religiosity' and their participation in secular society. The current Québec premier François Legault introduced a 'secularism law' prohibiting a public employee from wearing religious symbols at work which was passed on June 16, 2019. This law reminds us of the Parti Québécois's Charter of Values, also known as Bill 60, which proposed banning doctors and nurses from wearing conspicuous religious symbols before it died out in 2014. The 'secularism law' and the Charter of Québec Values have something in common: they deploy the narrative of state neutrality to limit a public employee's rights, such as judges, police officers, and teachers, from wearing religious symbols at work. The bill now formally bans teachers, judges, police officers, and daycare workers from wearing items like hijabs, crucifixes, kippahs, and turbans while in the course of their duties. Although CAQ and Legault did 
not explicitly mention a specific group, many believed that the law disproportionately targets minorities, including some but a tiny handful of Muslim women working in government-funded sectors such as teachers and daycare workers.

The case above elucidates that the state policy of neutrality and politics of recognition of minority only preserved privilege and maintain differences in a liberal secular society. Concerned about recent development in Québec society, Charles Taylor, who in the last decade was among the strongest proponent of limiting religious symbols and dress codes for minorities in the name of state neutrality, has changed his opinion and recalibrated his stand on the issue. He argued that secularism law plays on Québec's fears and may instigate further stigmatization of minority Muslims, hate speech, or even actual assault against Muslims (Riga, 2018; Taylor, 2017).

Given that the history of secularism in Canada closely represented the will and expressions of the Christian majority, one can imply that the secular project in Canada has reproduced the authoritarian side of liberalism that preserved the privilege and augmented the culture of the traditional majority. In response to this project, religions, especially Islam, instead of disappearing in the public sphere, re-manifested to play more important roles to maintain differences, strengthening the polarization between majority and minority.

\section{Indigenous difference and inequality}

The same vigorous public and political concerns about Muslims' 'religiosity' and their participation in secular society are extended to new converts. The documented life story of Dawood, a man from the James Smith First Nation in Saskatchewan who converted to Islam, is an excellent case in point (Bell, 2013). Growing up in an abusive environment, Dawood is familiar with common social pathologies such as drinking, addicting to crack cocaine, and spending time in a detention facility. The personal problems that he faced are by no means uncommon: Like many other Indigenous individuals, Dawood is a victim of systemic racism in many sectors of Indigenous life, from the gap in education and economic opportunity to unequal legal enforcement and distribution of justice. Dawood's case represents the many stories of inequality that Indigenous individuals experienced in contemporary Canada. His story also serves as a reminder of the limit of the secular premise to promote equality. It implies that despite the various attempts from the liberal state to emancipate and remedy the life conditions of Indigenous people, their overall social and economic lives have not improved.

Knowing that he could not find an immediate solution to the systemic racism he experienced within his current Indigenous perspective, Dawood searched for an answer elsewhere. Unlike many other Indigenous individuals who chose to revive 'authentic' indigenous roots in defining their identity and the struggle for equality, Dawood took a different path, opting to embrace Islam, a religion he came across when he was suicidal. Despite his brief encounter with Islam, Dawood was confident that becoming a Muslim would transform his life. The Islamic tradition's stand on personal discipline and attachment to the higher spiritual being vis a vis the materialistic lifestyle dominant in Western secular society might have been the factors leading to his conversion. Wilfred Cantwell Smith has eloquently captured this tendency decades ago, arguing that Muslims are more likely than participants of other religious traditions to present Islam as "an organized and systematized entity" (Eickelman \& Piscatori, 1996, p. 39). In Dawood's case, being Muslim acquired him 
a solid personal and political significance than being a participant of other religious traditions in part because of his self-conscious identification with the Islamic ethical stands against the perceived corruption and injustice in the modern secular world.

LikeallotherCanadian Muslims, Dawood received equal constitutional rights in the multicultural society of Canada. However, in the course of his struggle for justice and equality, he continued to experience systemic racism and injustice that he could not find a way to transcend within his Indigenous perspective, leading him to Islam that he thought providing him with higher goals in his life. What Dawood did not realize is that his conversion to Islam was viewed algorithmically with suspicion by outsiders. Rather than viewing his attachment to Islam as a struggle for equality and emancipation, outsiders viewed it as an impending security threat to the secular society.

Dawood later realized that outsiders viewed his conversion to Islam as adopting radical Islamic agenda without further thought of what Islam meant for him. His attachment to Islamic piety seems to be the main reason why he was pathologized as dangerous and viewed with fear. What Dawood did was that instead of employing the authentic indigenous expressions sanitized by the majority Canadians such as songs, arts, dances, and stories, and hence acceptable by the majority standard, Dawood employed a model of a struggle for equality that the state's policy of recognition was unable to contain, that is, Islamic activism. His conversion to Islam immediately reinforced stereotypes about Islam and Islamic religiosity that were generally attached to Muslim immigrants. The extension of stereotypes about Islam and Islamic religiosity to new converts like him can be explained as follows: As the secular state depoliticized religion in the public sphere, it also permitted the faith to flourish in the private sphere. Therefore, the modern state's complete autonomy to limit the scope of religion to operate in the private sphere enabled Dawood's conversion to any religion and guaranteed his rights to practice the faith individually without interference. But when the said religion turns to be Islam, that is, the one that incites the primordial threat to the common understanding of Canada as essentially Christians and simultaneously secular in its political ethos and cultural values, then the whole story of his conversion is scrutinized as an impending menace to the nation.

The inability of the liberal state to determine the scope of his struggle is best understood in how his life story was revealed to the public: the Canadian Security Intelligent Service labeled him an extremist and considered his views inappropriate in a secular and democratic Canada. Dawood made it clear that he was not an extremist. Islam, according to him, does not condone the use of violence against innocent civilians. However, due to the perceived threat that Islam poses to Canadians, his struggle for emancipation inspired by Islamic ethical stands was conflated with the activities of radical Muslims who have no connection whatsoever to him, so much so that he was labeled the 'Cree jihadist' (Bell, 2013).

Dawood's story prompts us to the limit of the secular project of promoting equality through the state's policy of recognition. On the one hand, the state's policy of recognition allowed Dawood to make his own choice to identify himself with a religious tradition he chose, which then precipitated the hardening religious differences in the public sphere. On the other hand, his identity was recognized only within the state's recognition framework. Since the familiar discourse of Islam and Muslim religiosity in Canada is one that viewed the faith as contrary to the state's definition of a secular society, his conversion to Islam was viewed 
as threatening the state's definition of national identity and majoritarian norms. Dawood's case exemplifies that the terms for emancipation and any struggle for equality remain in possession of the majority in power, not in the hand of minority subjects, so much so that his condition remains unchanged. Dawood's struggle is similar to what Franz Fanon described as a black slave's struggle for justice and liberty, only to find the anguish of freedom and justice defined by his owners (Fanon, 1967, p. 277).

Dawood's conversion to Islam that initially aimed at achieving equality, in turn, empowers and legitimizes the majoritarian norms embedded in the liberal state to be the framework that set the terms for defining an ideal society. In such a condition, instead of liberating himself, Dawood had to deal with the status quo or what Wendy Brown called as the "antidemocratic dimension of liberalism." He faced the Herculean task of transcending the condition of inequality that he and other Indigenous individuals are still struggling with and overcoming negative images and stereotypes against Islam that he shared with Muslim immigrants in the country. As he and other Canadian Muslims are still unable to achieve the common goals of secular society such as freedom, democracy, equality, and a tolerant way of life, we can infer that their inability to do so has less to do with their inherent deficiency or unwillingness to integrate into the mainstream Canadian society. Nor is their 'religiosity' a necessary menace to the existence and accomplishment of secular Euro-Atlantic society, preventing them from fully participating as citizens. The prerogative role of the secular state to define the nation's norms and identity and the self-understanding of the nation as essentially Christians and simultaneously secular in its political ethos and cultural values inadvertently carry the limits of the liberal premise of freedom and equality for citizens. When these limits were exposed in daily communal lives, it re-creates religious differences and tensions and intensifies the condition of inequality between majority and minority in the country.

\section{Conclusion}

The two cases discussed above allow us to reflect on the conventional understanding of secularity and modern liberal states' role in promoting equality for citizens. The assumption that Muslims in the West and their religiosity pose an existential threat and are unwilling to integrate is untenable. This view emerged from a self-understanding held by the majority of Canadians who saw the nation as essentially Christians and simultaneously secular, rather than from the actual capacity of Muslims to challenge them. From chronicling the formation of the secular in Canada, it is clear that secularism is a Christian discourse that emerged from the long-term negotiation between the Anglo-Protestant's social imaginary and the French Roman Catholics in the country and remained as it is.

While the two contesting collective imaginaries of a Christian nation eventually settled their differences and manifested in the institutionalization of the Charter of Rights and Freedom (1982), the contents of secularism were not fully defined. The Charter provided a constitutional basis for recognizing minority and civil equality, irrespective of one's ethnic or religious background. As the Charter is put into practice, the policy centered on assimilation and old forms of hierarchy was replaced with the state's policy that promotes neutrality, inclusivity, and greater recognition of Canada's cultural diversity. But the scope and applicability of recognition and equality remain in possession of those in power, that is, the majority of Anglo-Protestants. In Québec's case, as exemplified in the recently 
passed 'secularism law' or Bill 21, their applicability is subject to the sensibilities of the political status quo; most of them are the French Roman Catholics. When the scope of secularism and the premise of equality was contested by Muslim immigrants and Indigenous individuals in the form of religious and cultural differences, the majority quickly recalibrated it to reflect their understanding of secularism as a historically contingent to Christianity's evolution in Canada. It is precisely in this context, the presence of Muslims in Canada and their religiosity, including that of an Indigenous convert, are seen as an existential threat to national identity and majoritarian norms. Islam, in other words, is continuously being used to define the scope of secularism and sustain the collective identity of the majority population in the country.

The cases discussed above further reveal why religion has never really disappeared in the Canadian secular world. Whether it is Christianity or Islam, religion has always been a constitutive feature of the contemporary lives of Canadians, in part because its constitution that promises to limit religious expression in the public sphere enables the same, if not more robust, religious expression in the private sphere. In other words, the Canadian secular constitution has contributed to the exacerbation of religious differences and even political tensions among its citizens. For Canadian Muslims, the state's policy of recognition and equality has not been entirely transcending their conditions. The policy instead reproduced the condition of inequality that it initially sought to solve.

\section{Declaration of Ownership}

This article is my original work.

\section{Conflict of Interest}

There is no conflict of interest to declare in this article.

\section{Ethical Clearance}

This study was approved by the institution.

\section{References}

Alfred, T. (2011). Colonial stains on our existence. In M. J. Cannon \& L. Sunseri (Eds.), Racism, colonialism, and indigeneity in Canada (pp. 3-11). Oxford University Press.

Anderson, B. R. O. G. (1983). Imagined communities: Reflections on the origin and spread of nationalism. Verso.

Anderson, R. R., Crellin, J. K., \& Joe, M. (2000). Sprituality, values and boundaries in the revitalization of a $\mathrm{Mi}^{\prime} \mathrm{kmaq}$ community. In G. Harvey (Ed.), Indigenous religions: $A$ companion (pp. 243-254). Graham Harvey.

BBC. (2021). Canada: 751 unmarked graves found at residential school. Retrieved September 25 2021, from https://www.bbc.com/news/world-uscanada-57592243

Beaman, L. G. (2017). Deep equality in an era of religious diversity. Oxford University Press.

Bell, S. (2013, February 22, 2013). Creejihadist: How a boy from a Saskatchewan reserve came to embrace Islamist extremism. National Post. http://nationalpost.com/ news/canada/cree-jihadist-how-a-boyfrom-a-saskatchewan-reserve-became-anational-security-concern

Beyer, P. (2000). Modern forms of the religious life: Denomination, church and invisible religion in Canada, the United States and Europe. In D. Lyon \& M. v. Die (Eds.), Rethinking church, state and modernity: Canada between Europe and America (pp. 189-210). Toronto University Press. 
Bowlby, P. (2014). Canadian social immaginaries: Re-examining religion and secularization. In S. Levebvre \& L. G. Beaman (Eds.), Religion in the public sphere: Canadian case studies (pp. 25-43). University of Toronto Press.

Brown, W. (1995). States of injury: Power and freedom in late modernity. Princeton University Press.

Casanova,J.(2006). Rethinkingsecularization: A global comparative perspective. The Hedghog Review 8(1-2), 7-22.

Clark, W., \& Schellenberg, G. (Summer 2006). Who's religious? Statistics Canada Catalogue (11-008), 2-9.

Coulthard, G. S. (2014). Red skin, white masks: Rejecting the colonial politics of recognition. University of Minnesota.

Eickelman, D. F., \& Piscatori, J. (1996). Muslim politics. Princeton University Press.

Fanon, F. (1967). Black skin, white masks (R. Philcox, Trans.). Grove Press.

Flower, S., \& Birkett, D. (July 2014). (Mis) understanding Muslim converts in Canada: A critical discussion of Muslim converts in the contexts of security and society. TSAS (Canadian Network for reserach on terrorism, security and society) Working paper series 14-06, 1-20.

Fournier, P., \& See, E. (2014). The 'naked face' of secular exclusion: Bill 94 and the privatization of belief. In S. Lefebvre \& L. G. Beaman (Eds.), Religion in the public sphere: Canadian case studies (pp. 275-292). University of Toronto Press.

Hopper, T. (2018, August 18 2018). Here is what Sir John A. Macdonald did to Indigenous people. The National Post. https://nationalpost.com/news/canada/ here-is-what-sir-john-a-macdonald-didto-indigenous-people\#comments-area

Kazemipur, A. (2014). The Muslim question in Canada: A story of segmented integration. University of British Columbia Press.
Mahmood, S. (2013). Reply to Judith Butler. In T. Asad, W. Brown, J. P. Butler, \& S. Mahmood (Eds.), Is critique secular? Blasphemy, injury, and free speech (pp. 140147). Fordham University Press.

Mahmood, S. (2016). Religious difference in a secular age: A minority report. Princeton University Press.

Marhall, A., \& Mayes, B. (2016). The living and the dead: Ethno-history of Islam and identity in Winnipeg and beyond. Islam on the prairies: Tolerance, pluralism and diversity., University of Saskatchewan

O'Toole, R. (2006). Religion in Canada: Its development and contemporary situation. In L. G. Beaman (Ed.), Religion and Canadian society: Traditions, transitions, and innovations (pp. 7-21). Canadian Scholars' Press

Ramji, R. (2014). Mantaining and nurturing an Islamic identity in Canada - online and offline. In S. Levebvre \& L. G. Beaman (Eds.), Religion in the public sphere: Canadian case studies (pp. 97-120). University of Toronto Press.

Riga, A. (2018, October 19, 2018). Charles Taylor on religious gard ban: 'Dangerous, appalling, divisive'. Montreal Gazette. https://montrealgazette.com/news/ quebec/dangerous-appalling-divisivedestructive-charles-taylor-on-the-caqsreligious-symbols-plan

Rose, N. (1996). Governing "advanced" liberal democracies. In A. Barry, T. Osborne, \& N. Rose (Eds.), Foucault and political reason: Liberalism, neoliberalism, and rationalities of government (pp. 37-64). University of Chicago Press.

Taylor, C. (1994). The politics of recognition. In A. Gutmann (Ed.), Multiculturalism: Examining the politics of recognition (pp. 25-73). Princeton University Press.

Taylor, C. (2017, February 14, 2017). Neutralité de l'État: Le Temps de la Réconciliation. La Presse. http://plus. 
lapresse.ca/screens/36c5c72e-28b9-49dfba29-514fc56d647a\%7CpUtyV30bPPsb. html

Toronto Sun. (2017). Quebec passes Bill 62 forcing public to uncover faces to give or receive services. Retrieved September 25 2021, from https://torontosun.com/news/ national/quebec-passes-bill-62-forcing- public-to-uncover-faces-to-give-orreceive-services

Waite, P. B., \& Harris, C. (2008; last modified January 15, 2016). Sir Samuel Leonard Tilley. The Canadian encyclopedia. https:// www.thecanadianencyclopedia.ca/en/ article/sir-samuel-leonard-tilley 